\title{
Constitutional Rights for Danish Children
}

\author{
Caroline Adolphsen
}

\section{1 \\ Introduction to the Human Rights Framework in Denmark}

\subsection{Constitutional Rights}

The Danish Constitution entails a number of human rights - known as 'liberty rights - that provide an obligation for the State not to interfere in the constitutional right, but offers no positive obligations for the State to ensure the fulfilment of the rights for the individual. The Constitution, therefore, offers a more limited protection than the international human rights framework. Furthermore, it does not entail specific rules about children's rights except the right to receive primary education as mentioned below.

Today, everyone would agree that children enjoy the same freedom from intervention in their constitutional rights from the State as adults, ${ }^{1}$ unless specifically exempted from these rights. The core question is not if children are protected, but how they are protected. Are children entitled to exercise their rights independently or are the rights exercised by their parents? This chapter will provide an analysis of the most interesting rights from a child's right perspective. The analysis will draw upon the underlying legislation where the rights are more specifically detailed.

As Denmark has a dualistic approach to international human rights, as well as European Union law, I will start by explaining how international human rights are implemented into Danish legislation and what this means for the Convention on the Rights of the Child (CRC) and the European Convention on Human Rights (ECHR).

\subsection{International Human Rights in Denmark}

Danish liberty rights, as we know them today, were put in the Constitution in a constitutional amendment in 1953 and do not take the CRC or ECHR (or any other international human rights for that matter) into account. Though the

1 Jens Peter Christensen, Jørgen Albæk Jensen and Michael Hansen Jensen, Statsret (2nd edn, Jurist-og Økonomforbundets Forlag 2016) 279. The authors underscore that child's rights can, however, be subject to other limitations apart from adult rightsholder due to the child's lack of maturity. 
Constitution has been changed since, and incorporating the international human rights into the Constitution has been part of the political debate, this has not happened and no constitutional amendments are currently underway. ${ }^{2}$

Without following the procedure for constitutional amendments, ${ }^{3}$ the legislators cannot transfer sovereignty to foreign authorities such as the Council of Europe or the United Nations. Implementing international human rights into the Constitution cannot, therefore, be done in ordinary legislation or by interpreting the Constitution dynamically in light of present-day conditions. ${ }^{4}$

This question has been tried before the Danish Supreme Court on several occasions where the court has specifically rejected to interpret the Constitution in light of the international human rights framework. ${ }^{5}$ When interpreting the Constitution in Denmark, it is not relevant to draw upon the CRC, ECHR or case law from the European Court of Human Rights (ECtHR).

When looking at 'ordinary law' the picture is different. Here the abovementioned dualistic approach means that Denmark is free to implement international human rights into the legislation, but that the individual conventions have to be actively incorporated or ratified into Danish law in order for them to be part of the legislation unless the legislative body states that this is not necessary as Danish law already fulfils the convention at hand. ${ }^{6}$

2 The amendment is from 2009 and only covered the Act of Succession for the Danish Royal Family, while the rest of the Act - Lov nr. 169 af 5. juni 1953 - still stands. The Danish Constitution was passed in 1849 and has been amended in 1855, 1866 1915, 1920, 1953 and 2009.

3 Since 1915, there has been a very comprehensive amending procedure in place. A bill must be passed by two consecutive parliaments and then is put to a popular vote. More than 40 per cent (up until 45 per cent) of the voters must participate and vote in favour of the bill. Constitutional amendments must be, therefore, widely accepted and likely require political compromises. This explains why the change in 2009 did not involve putting international human rights into the Constitution. There simply was not a political majority to do so.

4 See Jens Peter Christensen, Jørgen Albæk Jensen and Michael Hansen Jensen, Grundloven med kommentarer (Jurist- og Økonomforbundets Forlag 2015) 45, where the authors argue that the Constitution must not be interpreted with a wider margin of appreciation or in light of the general legislation. See also Christensen, Jensen and Jensen, Statsret (n 1 ) 42 and 282 and, differently, Jonas Christoffersen 'Folkeretskonform grundlovsfortolkning' in Henning Koch (ed), Festskrift til Ole Espersen (Thomson 2004) 142. The latter was written before the above-mentioned case law and should be read in that light.

5 See U.2010.1547 H (20 March 2010), where the Supreme Court specifically states that international law does not have the same legal power as the Constitution ('folkeretten ikke har grundlovskraft') and Jens Peter Christensen, 'Internationale konventioners betydning for Højesterets grundlovsfortolkning' (2013) Ugeskrift for Retsvæsen 15. In case no. 159/2017 (18 January 2018) the Supreme Court stated that regardless of Denmark's international human rights obligations, the Constitution could not be interpreted in a way that adults without legal capacity should have a right to vote for parliament.

6 Ole Terkelsen, Folkeret og Dansk Ret (Karnov Group 2017) 16-17. 
The same goes for European treaty law, where the Danish Supreme Court in the Ajos case has specifically stated that the European Union principle about equal treatment could not set aside Danish legislation, as it was not a part of the European treaty law that had been incorporated into national legislation. ${ }^{7}$ Once incorporated the rules have the same legal value as other laws, but do not take precedence over the nationally decided legislation. The ECHR has been incorporated into national law and thus has the same legal status as other laws.

The CRC, on the other hand, has only been ratified, which means that Denmark considers itself bound by the principles of the convention. Thus, the legislator takes the convention into consideration when making child-related legislation, but individuals cannot make a claim against an authority based solely on the convention. ${ }^{8}$ Danish authorities and courts will, therefore, interpret national law in light of the convention and, when the interpretation can lead to different results, choose the interpretation most in line with the convention. But the Supreme Court does not consider itself to be bound by the non-incorporated conventions, nor do Danish legislators. While Denmark will typically not legislate against the ratified conventions, this does not mean that they cannot, only that they choose not to.

It is safe to say that the debate before the amendment in 1953 to the Constitution focused more on protection from State intervention than on positive rights and that children as individual human rights-holders were not on the agenda at that time. This might explain why children are not mentioned anywhere else than in the child-specific section 76 , which covers the right of children to receive free primary education.

The debate among parliament members (as part of the constituent body) before the bill, regarded the freedom rights as such and not their applicability on children. It was mentioned that placement of children in involuntary care (tvangsfjernelse) was indeed an intervention in the right to personal liberty

7 U.2017.824 H (6 December 2016). The Supreme Court pointed out that the principle is not a part of European treaty law that has been, in fact, adopted into Danish law. To interpret Danish law contra legem in order to fulfil the principle would be to act outside the boundaries of the division of power under section 3 of the Constitution.

8 See Hanne Hartoft, 'Children's Right to Participation in Denmark: What is the Difference Between Hearing, Co-Determination and Self-Determination?' in Trude Haugli and others (eds), Children's Constitutional Rights in the Nordic Countries (Brill 2019). 
(section 71) but the focus was on the intervention in the parental rights over the child more than the child's individual right to personal liberty. ${ }^{9}$ Children's individual rights to personal freedom, freedom of speech, etc. were not mentioned anywhere.

As a main rule, a child below the age of 18 cannot bring a case before a court in Denmark and cases have to be taken to court by the parent on the child's behalf. ${ }^{10}$ The same goes for administrative cases where the parent with custody over the child, who is also the child's legal guardian, ${ }^{11}$ carries out the child's rights.

This means that, in general, children cannot enforce their own rights if the parents are not willing to put the case before a competent body. Even if the child is granted an individual right to complain, he or she will not be able to carry out his or her adherent rights in lack of specific rules establishing such rights, i.e. legal standing. Neither the right or access to act on behalf of the child nor the parental duty to care for the child oblige the parent to start a case on behalf of the child, be that an administrative case or a court case..$^{12}$ In order to ensure the child's rights in cases where there is a risk of conflicting interest between the child and the parent with custody, specific rules allow for independent rights for children or require administrative or judicial procedures where the authorities play an active part to safeguard the child. A child aged 12 and above will, for instance, have a right to his or her own lawyer in cases regarding interventions (against the parents will) in the child's family life ${ }^{13}$ and

$9 \quad$ Helle Bødker Madsen, '§ 71' in Henrik Zahle (ed), Danmarks Riges Grundlov med kommentarer (2nd edn, Jurist- og Økonomforbundets Forlag 2006) 446; Christensen, Jensen og Jensen, Grundloven med kommentarer (n 4) 423.

10 In order to bring a case before the court, the plaintiff has to be above the age of 18 (and not under financial guardianship) and have a specific legal interest in the case (retlig interesse). See Ulrik Rammeskov Bang-Pedersen, Lasse Højlund Christensen and Clement Salung Petersen, Den Civile Retspleje (Pejus 2017) 54.

11 Section 1 of The Parental Responsibility Act (lovbekendtgørelse nr. 1417 af 1. december 2017, Forældreansvarsloven); section 1 of The Guardianship Act (lovbekendtgørelse nr. 1015 af 20. august 2007, Værgemålsloven).

12 Access to act on behalf of and duty to care for the child are detailed in The Parental Responsibility Act section 2, subsection 1.

13 Social Services Act (lovbekendtgørelse nr. 102 af 29. januar 2018) section 72, subsection 1. 
in all social welfare procedures the authorities must speak directly with the child to get the child's perspective - and the parent cannot oppose this. ${ }^{14}$

In the latter years different age limits have been introduced in different areas of the law allowing children an independent right to bring a case before an administrative complaint board. This is, for instance, the case regarding both voluntary measures and involuntary measures from the Social Welfare authorities where a child can complain from the time he/she turns 12 years old, ${ }^{15}$ even though his/her consent is not required in order to deem the measure voluntary.

\section{Constitutional Rights of Special Relevance for Children}

\subsection{Introduction}

As mentioned above, the right to receive primary education and the right to personal liberty are specifically stated in the Constitution. Alongside these are other classic liberty rights such as the freedom of expression ${ }^{16}$ and the right to privacy in one's home,$^{17}$ which, in my opinion, are especially relevant to discuss when the individual is a child. ${ }^{18}$ The chosen rights are regulated in different ways in the legislation with different types of remedies, showing different ways of ensuring children's rights.

Whereas the question about deprivation of liberty or access to one's home is a matter of consent/not consent, where the legislation must grant either the child, the parent or both (joint consent) access to invoke the right, freedom of speech is not an exhaustible right or a right that is connected to binding legal decisions. The different types of rights for children therefore has to be addressed individually.

The chapter will look at the development of the national rules regarding the child's independent right to privacy and physical integrity, understood as the individual right to consent to interventions in the right to personal freedom and the right to privacy in one's home. The chapter will also look at the right to

14 Social Services Act section 48, section 5o, subsection 3, and section 155 a, subsection 2.

15 Social Services Act section 167 , subsection 1 and section 168 , subsection 2.

16 Section 77. I will not elaborate on the freedom of assembly and freedom of association, as these rights have no specific child-related aspects that are not also discussed when addressing the freedom of expression.

17 Section 72.

18 Other rights are those connected to religion (s 67-70), the right to freedom of assembly and association (s $78-79$ ), the protection of property (s 73 ), the right to equal access to work (s 74) and the right to public relief (s 75 ). 
primary education and whether or not this is a right that the child can invoke him/herself.

The chapter will be concluded with some remarks on whether or not it makes a difference, in practice, the rights are folded out in the legislation and not in the Constitution as such.

\section{2}

4.2 .1

The Child's Right to Psychical Integrity and Privacy

The right to physical integrity and the right to privacy are considered core values in the Danish Constitution, and interventions in the right can only happen in accordance with the law. ${ }^{19}$

As mentioned above, it is a common understanding in Danish legislation that deprivation of a child's liberty is indeed protected by the Constitution, ${ }^{20}$ and the same goes for interventions in the child's home and correspondence. What is interesting from a legal perspective is not to establish this fact but to consider from which point the child can invoke the right to physical integrity and privacy. Or, put differently, when is parental consent to an intervention sufficient to put the situation outside the scope of the Constitution and consider the intervention voluntary?

While the question about the child's independent right to privacy has not been subject to case law or debate ${ }^{21}$ there is a long tradition in Danish legislation about regulating the child's right to physical integrity under section 71 , which covers both sentencing for criminal offences and deprivation of liberty

19 Section 71, subsection 1 of the Danish Constitution states that personal freedom is inviolable. Subsection 2 states that deprivations of liberty can only happen in accordance with the law. Section 72 states that one's home is inviolable and, as a main rule, searches of the home or of correspondence require a warrant. The section does not specifically state that interventions in the rights require a clear legal basis, but this is the common understanding in the legal literature. See Christensen, Jensen and Jensen, Grundloven med kommen$\operatorname{tarer}(\mathrm{n} 4) 439$.

$20 \quad$ Madsen, '§ 71' (n 9) 446; Christensen, Jensen and Jensen, Grundloven med kommentarer (n 4) 423 .

21 In Danish legislation, however, the child has no individual right to privacy unless living in a care facility. This can, for instance, be seen in the Social Services Act, section 64, subsection 3 , which presupposes that consent for social services to enter the family home can be given solely by the parent. This can be seen by the fact that the act only deals with setting aside the parents' objections if it is necessary to enter the family home as part of a child welfare case. The rule does not deal with the child's right to his/her home. The same applies in relation to house searches in cases where the parent is suspected of a criminal offence. In these cases, the warrant covers the entire house unless parts of it are explicitly inaccessible by the parent. 
for other reasons, for instance, involuntary placement of children and involuntary admissions to a psychiatric ward. ${ }^{22}$ In lieu of a common regulation or understanding of the question in the Constitution, however, the matter has traditionally been handled differently in social welfare legislation and mental healthcare legislation. Remarkably, from a children's rights perspective, the tendency in the legislation is actually to move away from assessment-based legislation and towards fixed age-limits.

\subsubsection{Age or Maturity—Fixed Limit or Individual Assessment?}

Both the Psychiatry Act ${ }^{23}$ and the Social Services Act ${ }^{24}$ consider parental consent to be sufficient to consider the treatment or placement voluntary if the child is below the age of 15 , which places the child without the rights of an individual deprived of his/her liberty. The child has no individual right to invoke his/her right to physical integrity.

This has, however, not always been the case regarding psychiatric treatment, and all the way back to the 1930s, children were believed to be independent right-holders in this area if they opposed the treatment and had the sufficient age and maturity to understand the situation. ${ }^{25}$ That is, if the child was considered insane and therefore covered by the judicial protection of the Psychiatry Act at the time. The child did not have the same individual right to oppose institutionalisation in other situations, which can be seen by the ECtHR case of Nielsen $v$ Denmark. ${ }^{26}$ In the case, the Court found that the parental consent given by the child's mother to his admission in a psychiatric ward put the admission outside the scope of section 5 of the ECHR, as it could not be considered involuntary. The essence of the case was that the parental consent on behalf of the child meant that he could not on his own exercise his fundamental right to personal liberty as no specific national legislation awarded him a right to do so.

22 Criminal offences are governed by the Penal Code (Lov nr. 977 af 9. august 2017) and the Administrative Justice Act. A child above the age of criminal responsibility is largely given the same rights as an adult offender. I will not touch upon the matter any further.

23 Lov nr. 116o af 29. september 2015 section 1, subsection 4. Up until 2015, no age-limit was written into the law and the change in 2015 was made with surprisingly little focus on the shift in view of child's rights. The law now states that treatment is not considered involuntary in the sense of the law if the patient is below the age of 15 and the custody holder has given an informed consent.

24 Section 52 , subsection 1.

25 Betænkning nr. 1068/1986 'Principbetænkning om tvang i psykiatrien' 386; Betænkning nr. 1109/1987 'Afsluttende udtalelse vedrørende udformningen af en ny lov om frihedsberøvelse og anden tvang i psykiatrien' 51 .

App no 10929/84 (ECtHR, 28 November 1988) para 73. 
Though there has been a rapid development in the duty to involve the perspectives of children in their decision-making ${ }^{27}$ the right to act on behalf of the child in Denmark still lies with the parent and the case would therefore in my opinion - still have the same result if it was brought before a Danish court today. ${ }^{28}$

The changes in the rules regarding psychiatric treatment have led to a debate among legal scholars ${ }^{29}$ on whether or not the current legislation regarding psychiatric treatment provides a sufficient legal basis for interventions that the child resists. Is the parental consent sufficient to consider the treatment voluntary or is it necessary with a clear legal basis as generally required in Danish administrative law for interventions in the rights of the individual. ${ }^{30}$ Whereas everyone agrees that there is no clear legal basis for the interventions, there is no such common ground on whether or not this is in fact necessary with the consequence that children below the age-limits must be granted constitutional protection, if they have the sufficient maturity, even if the legislation does not provide these rights.

As the Constitution is written and construed, it cannot, in my opinion, in itself be considered unconstitutional to have (or to introduce) an age-limit in the legislation, deciding from which age children can invoke their right to physical integrity themselves.

The rationale behind the Constitution was never to give specific rights to the child independent of his or her parents. ${ }^{31}$ The question is not whether the child has rights or not - of course he/she do - but whether or not these rights are carried out by the child or the custody-holder. It is not only the legislation but also the parental consent that puts the situation outside the scope of constitutional protection.

\footnotetext{
27 As shown by Hartoft (n 8).
}

28 See contrary Helle Bødker Madsen, 'Mindreåriges retsstilling efter psykiatriloven' (2015) 36 Ugeskrift for Retsvæsen 283-289.

29 Madsen, 'Mindreåriges retsstilling efter psykiatriloven' (n 28) 284; Helle Bødker Madsen, Psykiatriret (2. edn, Jurist- og Økonomforbundets Forlag 2017) 48-51; Caroline Adolphsen, 'Børns ret til personlig frihed i velfærdsretten: - fra et dansk perspektiv' in Bjørn Henning Østenstad (ed), Selvbestemmelse og tvang i helse- og omsorgstjenesten (Fagbokforlaget 2018) 84.

$30 \quad$ Karsten Revsbech and others, Forvaltningsret: Almindelige Emner (6th edn, Jurist- og Økonomforbundets Forlag 2016) 180-188.

31 Madsen, 'Mindreåriges retsstilling efter psykiatriloven' (n 28) 284; Madsen, Psykiatriret (n 29) $48-51$. 
4.3.1 Introduction

Section 76 of the Constitution states that all children in compulsory school age have a right to receive free education in the public school system unless the parents themselves provide a private alternative of the same standard as the public education. Though expressed as a right, the rule imposes a duty upon the child, which can be seen by the fact that the section presupposes that there is a compulsory school age ${ }^{32}$ where the child must attend school. The section also puts a duty upon the parents to make sure that the child receives primary education.

However, the Constitution does not elaborate further on the amount of education or the length of the compulsory school age and these matters are handled in the Public School Act. ${ }^{33}$ What the Constitution does ensure is some level of primary education, and, importantly, that all compulsory education in public schools is without cost. This is specified in the Public School Act ${ }^{34}$ stating that all expenses related to teaching equipment are paid by the local authorities. ${ }^{35}$

4.3.2 The Parent's Duty to Ensure the Child Receives Primary Education As mentioned above, the parent is obliged to ensure that the child receives primary education in the public school system or at a private alternative of the same quality.

Though the child has a duty and right to receive primary education, it is a parental responsibility to make sure that the child actually attends school, ${ }^{36}$ whether it is a public school, a private school or home-schooling. The parent

32 Christensen, Jensen and Jensen, Grundloven med kommentarer (n 4) 487. The duty for the child to receive primary education is clearly stated in the Public-school Act (Lovbekendtgørelse nr. 1510 af 14. december 2017, Folkeskoleloven) section 32.

33 Not all subjects taught in school are mandatory pursuant to the Public School Act. Parents can apply for the child to be exempted from religious education if the parents declare that they will provide for the child's religious education. This is due to the fact that the religious education in public schools is primarily focused on Christianity. See section 6 of the Public School Act.

34 Section 49.

35 This, however, does not include clothes for gym class and writing equipment, which the parents have to cover themselves. If computers are used in class and the pupils either do not have computers or do not want to bring their own computer to school, the local authority has to provide computers for the pupils. See the Danish Ombudsman in Fов 2010.1808. See also Christensen, Jensen og Jensen, Grundloven med kommentarer (n 4) $487-488$.

$36 \quad$ See section 35 of the Public School Act. 
decides which type of school the child attends and the child itself cannot decide to change school without parental consent.

The child cannot complain to the school or the local authority in charge of providing public schools about the parent's choice of school or inability or unwillingness to make sure that the child goes to school, ${ }^{37}$ and the school-related legislation does not provide a solution for the child in these cases. However, the school staff at both public and private schools have a duty to report to the social services if they have knowledge of or reason to assume that a child is in need of social support due to (amongst other things) illegal absence from school. ${ }^{38}$ If the absence is due to the fact that the parent is not willing (but is capable) of ensuring the child's education, social services can - in coherence with the system for interventions in the life of the family ${ }^{39}$ - issue an administrative order demanding that the parent makes sure that the child attends school. ${ }^{40}$ If the parent does not fulfil the order, the family can lose the right to child-related and housing-related benefits until the child receives education again. ${ }^{41}$ The enforcement of the right to primary education is thus secured by financial restrictions. A parent's unwillingness to ensure the child's school-attendance can, depending on the circumstances, also be seen as a more general social problem and can be part of the reasoning for other interventions in the family.

\section{Concluding Remarks}

As shown above, there is no common legal understanding of children's rights in Denmark. This means that although the child in principle has the same constitutional protection as an adult, he/she does not necessarily have independent rights that he/she can invoke, as the rights are typically invoked by the parents.

37 See Inger Dübeck, '§ 76' in Henrik Zahle (ed), Danmarks Riges Grundlov med kommentarer (2nd edn, Jurist- og Økonomforbundets Forlag 2006) 525.

38 Pursuant to the Social Services Act section 153, subsection 1, no. 3 and Administrative Act (nr. 1466 af 16. december 2010) section 1, subsection 1 no. 2. The Administrative Act, which entails the duty to report for privately employed school staff, has not been updated since 2010 and, therefore, does not specifically refer to absence from school as an event that triggers a duty to report. However, the school staff do have a general duty to report if the child needs social support regardless of the cause of the child's needs and, therefore, also if the needs arise or become clear in a school-related setting.

39 See Caroline Adolphsen, 'Children's Right to Family Life in Denmark' in Trude Haugli and others (eds), Children's Constitutional Rights in the Nordic Countries (Brill 2019).

$40 \quad$ Under the Social Services Act section 57 a, subsection 1, 2 no. 1 and 3 no. 1.

41 Social Services Act section 57 a, subsection 6 . 
The independent rights that the child does have are only stated in the ordinary legislation and can be thus changed or removed under an ordinary legislative procedure just as is the case regarding psychiatric treatment, as shown above. By amending specific rights for the child into the Constitution or even by making a joint set of children's rights in the legislation, Denmark could certainly strengthen the child's individual rights. As the legislation is constructed now, the primary legal protection of the child is provided by the parent. Therefore, it is the parents' rights on behalf of the family/child and not the child's rights that has been the main focus in the newer Danish legal history. There is thus a tendency that children's rights in Denmark are rights to be involved/heard/participate together with the parent instead of a right to act instead of the parent.

\section{References}

Adolphsen C, 'Children's Right to Family Life in Denmark' in Trude Haugli and others (eds), Children's Constitutional Rights in the Nordic Countries (Brill 2019).

Adolphsen C, 'Børns ret til personlig frihed i velfærdsretten: fra et dansk perspektiv' in Bjørn Henning Østenstad (ed), Selvbestemmelse og tvang i helse- og omsorgstjenesten (Fagbokforlaget 2018).

Christensen JP, 'Internationale konventioners betydning for Højesterets grundlovsfortolkning' (2013) Ugeskrift for Retsvæsen.

Bang-Pedersen UR, Christensen LH and Petersen CS, Den Civile Retspleje (Pejus 2017).

Christensen JP, Jensen JA and Jensen MH, Grundloven med kommentarer (Jurist- og Økonomforbundets Forlag 2015).

Christensen JP, Jensen JA and Jensen MH, Statsret (2nd edn, Jurist- og Økonomforbundets Forlag 2016).

Christoffersen J, 'Folkeretskonform grundlovsfortolkning' in Henning Koch (ed), Festskrift til Ole Espersen (Thomson 2004).

Hartoft H, 'Children's Right to Participation in Denmark: What is the Difference Between Hearing, Co-Determination and Self-Determination?' in Trude Haugli and others (eds), Children's Constitutional Rights in the Nordic Countries (Brill 2019).

Madsen HB, Psykiatriret (2nd edn, Jurist- og Økonomforbundets Forlag 2017).

Madsen HB, 'Mindreåriges retsstilling efter psykiatriloven' (2015) Ugeskrift for Retsvæsen 36 .

Revsbech $\mathrm{K}$ and others, Forvaltningsret: Almindelige Emner (6th edn, Jurist- og Økonomforbundets Forlag 2016).

Terkelsen O, Folkeret og Dansk Ret (Karnov Group 2017).

Zahle H (ed), Danmarks Riges Grundlov med kommentarer (2nd edn, Jurist- og Økonomforbundets Forlag 2006). 